\title{
Actions developed at the Instituto de Medicina Integral Prof. Fernando Figueira to confront the COVID-19 pandemic
}

\section{Tereza Campos 1}

https://orcid.org/0000-0002-4960-6519

Afra Suassuna 2

Dttps://orcid.org/0000-0003-4027-3719

Ítala Nóbrega 3

https://orcid.org/0000-0002-5355-2277

Jéssica Cavalcanti de Almeida 4

D https://orcid.org/0000-0002-5525-5305

Madalena Oliveira 5

iD https://orcid.org/0000-0002-6528-525X
Maria Júlia Gonçalves de Mello 6

(iD) https://orcid.org/0000-0003-4645-8343

Suzana Ferraz 7

(iD) https://orcid.org/0000-0002-5611-0482

Suzana Mota 8

D https://orcid.org/0000-0002-5203-8401

Gisele Pereira 9

(iD) https://orcid.org/0000-0002-1864-5494

Adriana Scavuzzi 10

iD https://orcid.org/0000-0002-6505-2894

1-10 Instituto de Medicina Integral Prof. Fernando Figueira. Rua dos Coelhos, 300. Boa Vista. Recife, PE, Brasil. CEP: 50-070-902. E-mail: afra.suassuna@imip.org.br

\begin{abstract}
The COVID-19 pandemic has brought countless challenges to the health institutions around the world, especially those located in countries such as Brazil, with large territorial dimensions and many social and economic differences. This technical report aims to publish the actions carried out and the products developed at the Instituto de Medicina Integral Prof. Fernando Figueira (IMIP) before and during the pandemic - from January 31 st to September 4th, 2020 - facing it efficiently and effectively, seeking institutional sustainability. The mobilization of the professional staff at the institution was fundamental to create protocols ofassistance, adapt the physical structures in the hospital and outpatient care, care for the health professionals, offer teaching and research activities in the distance mode, articulate management members to make decisions based on systematically collected data on the pandemic situationat real time. All actions were carried out with a single objective of assisting all the patients affected by COVID-19 admitted at the institution.

Key words COVID-19, Coronavirus infections, SARS-CoV-2, Technical report
\end{abstract}




\section{Introduction}

Coronaviruses have been known since 1960 as etiological agents of disease in animals. Outbreaks of SARS-CoV, the etiological agent of Severe Acute Respiratory Syndrome (SARS) and MERS-CoV of Middle Eastern Respiratory Syndrome have been previously described as severe public health challenges. ${ }^{1}$

On December 31, 2019, the World Health Organization (WHO) received a report of the occurrence of "pneumonias of unknown cause" in humans in the Chinese city of Wuhan, Hubei Province, China. ${ }^{2}$

In the early 2020, WHO member states were alerted about the occurrence of these cases whose agent implied a new coronavirus. On January 30, WHO declared the disease caused by the new coronavirus an International Public Health Emergency, and in February, Brazil declared a Public Health Emergency of International Concern (PHEIC).3,4

On February 11, WHO named the new coronavirus as SARS-CoV-2 and the disease as COVID19. One month later, on March 11, COVID-19 was characterized by WHO as a pandemic.

With the declaration from PHEIC, the State of Pernambuco, through the Secretary of Health (SES$\mathrm{PE})$, called the Instituto de Medicina Integral Professor Fernando Figueira (IMIP), in February 2020 , to become a reference in the State, initially, for pregnant women, puerperal and newborns and, later, for adults affected by SARS, as part of the strategy to combat COVID-19. Encountered with an enormous challenge, in the face of the disease until then little was known and with threatening predictions, the institution made a commitment to assist the population in this critical scenario of confrontation. COVID-19 was configured as a disease with a varied clinical spectrum. Most patients may be asymptomatic or oligosymptomatic, but in approximately $20 \%$ of the cases there is a need for hospital care because they present SARS, which is a flu syndrome that evolves with respiratory dyspnea/discomfort OR persistent pressure in the chest $\mathrm{OR} \mathrm{O}_{2}$ saturation less than $95 \%$ in ambient air OR bluish coloration of the lips or face of which about $5 \%$ which may need ventilatory support in the intensive care units (ICU). ${ }^{1}$

Until September 4, 2020, 26,121.999 cases of COVID-19 were confirmed worldwide, with 864,618 deaths. In Brazil, 4,041.638 cases were confirmed, resulting in 124,614 deaths, and in Pernambuco, there were 131,230 cases, with 7,645 deaths. 5
WHO and the Pan American Health Organization (PAHO) provided technical support for Brazil and other countries in the preparation and response to the COVID-19 pandemic. Faced with many challenges this disease has brought to the world, prevention stands out, especially in regard to the development of an effective vaccine accessible to all. 6

A philanthropic institution that exclusively assists patients of the Sistema Único de Saúde (SUS), (Public Health System) with its historical experience in the areas of health care, teaching, research, in addition to community extension and reference center in several medical and non-medical specialties, it has become a reference in the Pernambuco State health network for suspected cases of SARS initially for pregnant women, puerperal and newborns, and afterwards for adults.

In Pernambuco, the first notification in the Sistema de Informação da Vigilância Epidemiológica da Gripe (SIVEP-Gripe) (Influenza Epidemiological Surveillance Information System) of a patient suspected of COVID-19 occurred on March 12, 2020.7 At IMIP, the first notification regarding hospitalized patients suspected of SARS/COVID-19 symptoms occurred on March 20, totaling 2,111 suspected cases in the institution by September $4^{\text {th }} .7$

Faced with this scenario, this report aims to outline the institutional insertion in the context of care for patients suspected of SARS-CoV-2 infection and the activities developed during the COVID-19 pandemic. To this end, the analysis of the institutional technical documents and dissemination since the beginning of the pandemic until September 28, 2020 was conducted.

\section{Epidemiological Data}

For the analysis of epidemiological data of patients admitted to IMIP suspicion of COVID-19, 68 patients who waited for the result of the Reverse Transcription - Polymerase Chain Reaction (RTPCR) were discarded for SARS-CoV-2 research and 2,043 patients were considered with this result released in the period from March 20 th to September 4, 2020.

Since April, there was an increase in the notifications of suspected cases and the collection of RTPCR for SARS-CoV-2 and then a decline began in August. The highest percentage of positivity of RTPCR for SARS-CoV-2 occurred in July (65.2\%), followed by May (61.1\%) (Figure 1).

Considering the positivity of RT-PCR for SARS- 
Distribution of 2,043 patients who performed Reverse Transcription - Polymerase Chain Reaction (RT-PCR) SARS CoV2 in nasal/oral swab according to the month of collection and tested positivity (\%). IMIP, March 02 to September 04 , 2020.

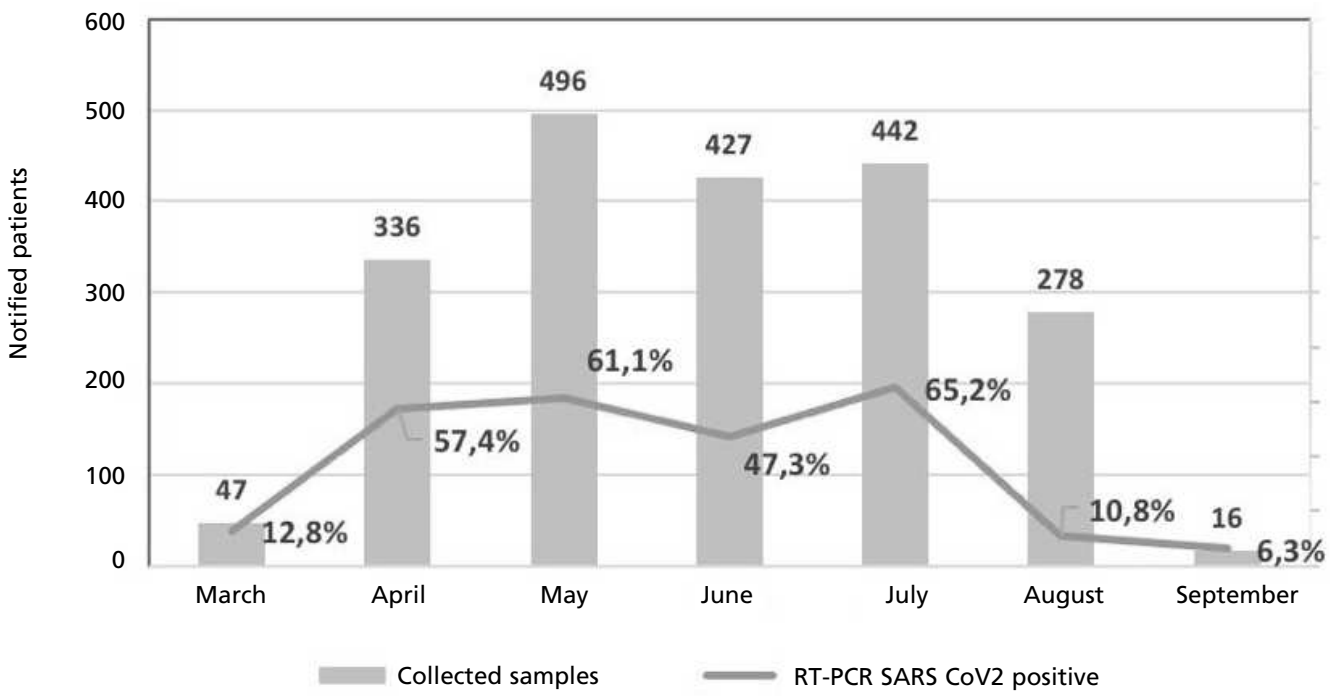

Source: Hospital Epidemiological Surveillance - IMIP, September/2020.

CoV-2, according to the age groups, 178 cases of young adults aged 20 to 29 years old and those from 30 to 39 years old had 150 cases and were the most affected. Afterwards, 140 cases aged 60 to 69 years old, from 5 to 19 years old had 103 cases, there were 102 cases aged from 50 to 59 years old, and from 70 to 79 years old had 80 cases. The high number of children under the age of one month, therewere 59 cases, and this also explains the fact that IMIP is a reference for newborns (Figure 2).

Regarding to the notification criteria for suspected cases of COVID-19, 1,399 (68.5\%) met the criteria for influenza syndrome (IS) and 630 (30.9\%) for SARS. Of those reported for SARS, 373 $(59.2 \%)$ were positive and $640(45.8 \%)$ were positivefor IS. Considering the distribution of reported cases by sex, there was a predominance of females (63.5\%). Among all reported cases, 570 (27.9\%) corresponded to pregnant women or puerperal who had recently given birth,due to the fact that IMIP is a reference for pregnant women and puerperal.

As for the evolution of all the patients, 1,334 $(65.3 \%)$ were discharged from the hospital. The evolution on death, all of the reported cases occurred in $20.2 \%(412 / 2,043)$ of the patients and among these, the majority, $67.2 \%(277 / 412)$ presented detectable results for SARS-CoV-2 (Table 1).
The notification of influenza syndromes (IS) of inpatients with mild symptoms and patients in the preoperative period of elective surgeries is now performed in the e-SUS Notification system from June 19.8 At IMIP 1,028 cases were notified until September 4 th that did not participate of this analysis.

The importance of the epidemiological surveillance stages performed at the hospital itself, included notification, investigation and processing of cases, essential for the composition of the official databases on the disease, is highlighted.

\section{Health care}

IMIP maternity clinic, inaugurated in 1987, has had throughout its existence a vanguard posture in women's health care, offering a quality service, providing patients with an integral and humanized care.

The first protocols to care for patients suspected or confirmed by the infection of the new coronavirus were for the newborns ${ }^{9}$ (published on March $16^{\text {th }}$ ), after, for pregnant women and puerperal 10 (published on March 24th) and then adults in the ICU.11 Since then, all have been updated and the first two have been referenced by the Ministry of Health - mainly 
Figure 2

Distribution of the 2,043 patients notified at the Epidemiology Center at IMIP who performed Reverse Transcription - Polymerase Chain Reaction (RT-PCR) SARS CoV2 in nasal/oral swab according to age and positivity of tests. IMIP, March 02 to September $04,2020$.

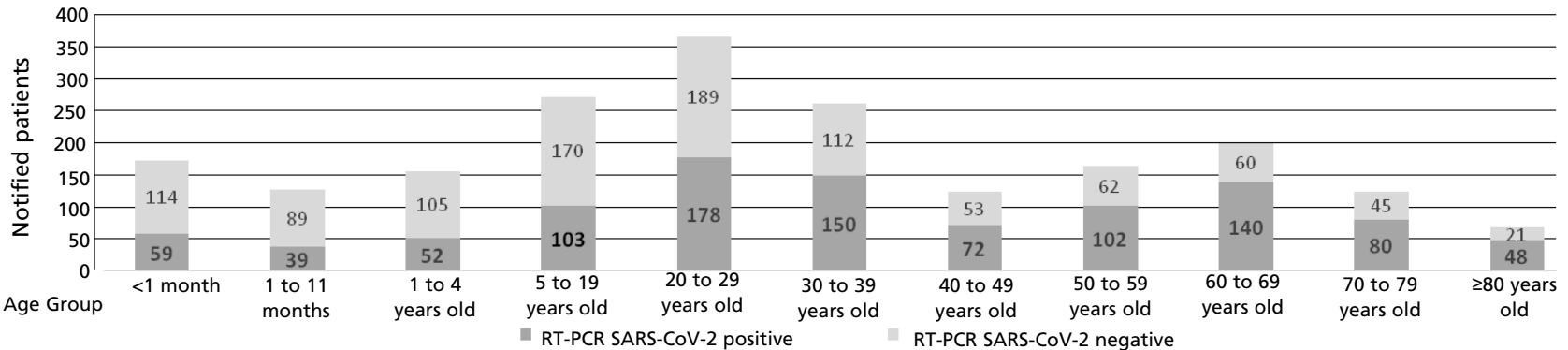

Source: Hospital Epidemiological Surveillance - IMIP, September/2020.

in the area of maintenance and protection of breastfeeding during the pandemic, as well as being models for care in other health institutions.

In view in the increase of cases of patients affected by IS, SARS and COVID-19, aiming to meet this demand, IMIP agreed with the Secretaria Estadual de Saúde de Pernambuco (SES-PE) (Pernambuco State Health Secretary) to open 50 new adult ICU beds, 20 pediatric ICU beds and 53 infirmary beds for pregnant women and puerperal.

For the structuring and adequations of the sectors of the institution, it was based on the Technical Notes Numbers $04 / 2020$ and $07 / 2020$, RDC Number 50 and Ordinance Number 467 on March 20, 2020, published by the Ministry of Health.3,12-14 In obstetric, adult and pediatric emergencies, the first adequations performed were: dimensioning of the environments and delimitation of space, since the arrival of the patient at the institution until hospitalization in the destination sector. Aiming for space delimitation, stricter protocols were elaborated and applied to comply with the distance recommended by health authorities. Clean and critical areas were demarcated, the waiting service was implemented through pre-triages, in order to identify at an early stage, the cases that needed respiratory isolation, besides the disposition and the control of Individual Protection Equipment (IPE) for all health professionals.

Based on the Technical Note Number 04/2020, for the ICUs, protocols were elaborated and instituted, through training, for the procedures developed in the sectors that suffered important and indispen- sable adaptations to assist suspected and confirmed patients of COVID-19. The IPEs were guaranteed for the professionals and the control of drugs dispensed by the pharmacywere maintained, in addition to supplies and printed materials. The assigned team for this care was restricted and exclusively for this purpose, to prevent the spread of infection to other professionals at care.

Simultaneously it was necessary adjustments of organization and logistics of several services that compose the hospital structure, such as: the nutritional service that adapted a way of dispensing food; the supply of medicines from the pharmacy; flow of professionals and patients in the imaging sector; the process of clothing; the security service, intensifying the control of visitations and companions; the cleaning service working on specific care of residues and the material and sterilization department, which implanted the reception and processing of the materials using a management action plan for precaution, prevention and the control on the transmission of SARS-CoV-2.

In the central ambulatory at IMIP, which is a reference in several medical and non-medical areas, in care for children, adolescents, adults and elderly of all age groups, several adaptations were necessary, such as the restriction of the amount of outpatient care, in order to avoid the increase of the contagiondisease. Following the guidelines of Ordinance Number 467 on March 20th 2020 from the Ministry of Health, to ensure the maintenance of safety for the patients and professionals, the teleservice of the ambulatory at IMIP was implemented in April 2020. 
The teleservice was initiated after the acquisition of equipment and training of several professional categories. Consultations, monitoring, diagnostics, surgical appointments and active searches were carried out, totaling 19,726 teleservices from April to September $4^{\text {th }}$. These appointments were maintained after the return of the face-to-face activities, prioritizing the patients belonging to the risk group and residents in areas of difficult access.

In view of the necessityin welcoming its professionals and students, the mental health team at IMIP implemented, during the months of April to August, an online service. Faced with restriction of face-toface care, the professional or student who needed psychological care, hospitality listening or clinical psychiatric care for a brief support, could count on psychologists and psychiatrists which were available in a rotational format in on-duty schedule, and in attendance by spontaneous demand, having the professional/student directed for face to face care, at arranged time, when the necessity was evaluated. The welcoming has brought countless benefits to employees who were in the front line at such a difficult time.

Between the months of May and July, IMIP was hired by SES-PE to perform RT-PCR tests on patients admitted to the institution itself and in the units of Prof. Martiniano Fernandes Foundation, a social health organization that manages some health units and hospitals in the State of Pernambuco. For this, the structure of the research laboratory at the institution was used, which had its physical space adequate to the needs of the service and counted on the hiring biomedical professionals and laboratory technicians. During this period, about 12 thousand tests were performed, with the release of results in the fastest way that benefitted the service to patients and professionals of the institution.

For the collection of nasal secretion samples for the RT-PCR, the entire on-duty collector team from the laboratory was mobilized to assist hospitalized patients, pediatric and obstetric emergencies, and the emergency room (SPA). For the collection of samples from outpatients and professionals from IMIP, 10 pediatric outpatient rooms were used and two professionals were recruited for full-time care.

In August, testing for SARS-CoV-2 began at the Laboratório de Saúde Pública de Pernambuco (LACEN-PE) (Public Health Laboratory of Pernambuco), and the collection of nasal secretion

Table 1

Distribution of hospitalized patients who performed the Reverse Transcription - Polymerase Chain Reaction (RT-PCR) test for SARS-CoV-2 from 03/2020 to 09/04/2020 according to sex, occurrence of pregnancy/perperium, presence of SARS at admission and evolution. IMIP, September/2020.

\begin{tabular}{|c|c|c|c|c|c|c|}
\hline & \multicolumn{2}{|c|}{ Total } & \multicolumn{4}{|c|}{ RT-PCR SARS-CoV-2 } \\
\hline & \multirow[t]{2}{*}{$\mathbf{N}$} & \multirow[t]{2}{*}{$\%$} & \multicolumn{2}{|c|}{ Positive } & \multicolumn{2}{|c|}{ Negative } \\
\hline & & & $\mathrm{n}$ & $\%$ & $\mathrm{n}$ & $\%$ \\
\hline Patients tested & 2043 & 100.0 & 1023 & 50.1 & 1020 & 49.9 \\
\hline \multicolumn{7}{|l|}{ Sex } \\
\hline Male & 744 & 36.4 & 370 & 49.7 & 374 & 50.3 \\
\hline Female & 1299 & 63.6 & 653 & 50.3 & 646 & 49.7 \\
\hline \multicolumn{7}{|l|}{ Pregnant woman/Puerperal } \\
\hline Yes & 570 & 27.9 & 275 & 49.2 & 295 & 50.8 \\
\hline \multicolumn{7}{|l|}{ SARS at admission } \\
\hline No & 1399 & 68.5 & 640 & 45.8 & 759 & 54.2 \\
\hline Yes & 630 & 30.9 & 373 & 59.2 & 257 & 40.8 \\
\hline No information & 14 & 0.7 & 10 & 71.4 & 4 & 28.6 \\
\hline \multicolumn{7}{|l|}{ Evolution } \\
\hline Discharged & 1334 & 65.3 & 568 & 42.6 & 766 & 57.4 \\
\hline Death & 412 & 20.2 & 277 & 67.2 & 135 & 32.8 \\
\hline Transferred & 229 & 11.2 & 161 & 70.3 & 68 & 29.7 \\
\hline Abandoned treatment & 39 & 1.9 & 12 & 30.8 & 27 & 69.3 \\
\hline In treatment & 29 & 1.4 & 5 & 17.2 & 360 & 82.8 \\
\hline
\end{tabular}

Source: Epidemiological Hospital Surveillance -IMIP, September/2020. 
samples from outpatients and professionals from IMIP gained new structure, with exclusive rooms for this purpose. Until September $4^{\text {th }}$ more than 14 thousand RT-PCR exams for SARS-CoV-2 were performed. Many strategies were designed and performed at IMIP to confront COVID-19 and the institution continues to assume this position of commitment to the population.

\section{Training}

In a joined action promoted by the Superintendências de Atenção à Saúde e de Ensino, Pesquisa e Extensão (Superintendencies of Health Care and Teaching, Research and Extension department), along with the health professionals, were trained in a permanent, continuous and systematic way, aiming primarily at their own safety and focusing on the following topics related to COVID19: epidemiological situation in Brazil and Pernambuco; signs and symptoms; standard precautionary measures, droplet, aerosols and contact; importance of the use of IPE, demonstration of the attire and unattirestages; and the performance of the participants on the step by step of hands sanitation.

Between February and August approximately 215 groups were trained, respecting the limit of 10 people in each group and the social distancing. The trainings always occurred in wide places (auditoriums and service rooms), ventilated and all the professionals were using masks, totaling 2,152. As for the category of trained professionals, $21.6 \%$ $(n=465)$ were of superior level (social workers, dentists, nurses, pharmacists, physiotherapists, physicians and nutritionists), 69.0\% ( $\mathrm{n}=1,485)$ medium level (nursing technicians, administrative, janitors, laboratory technician, nutrition assistant, pharmacy assistant, oral health assistant and students), 3.7\% $(n=80)$ elementary level (sanitation assistant, maintenance and stretcher bearers) and $5.7 \%(n=122)$ not identified.

Faced with the pandemic, the shared management of various services proposed by the hospital needed to assume an even more proactive role, in the search for the quality of service provided and in ensuring the safety of the professionals and patients.

\section{Teaching and Research}

On March 18, 2020, following the guidelines of the board members of IMIP, current legislation, decrees of the federal, state and municipal governments, the Superintendence of Education, Research and Extension suspended the face to face activities for students of technical education, undergraduates and graduate in wards and outpatient institution, except for the activities at the wards for residents and students in their last year of graduation. Individualized discussions of cases in the wards became a routine, thus avoiding agglomerations in the hospital environment during clinical visits.

The theoretical activities progressively started to be carried out remotely, following a schedule established by the teaching board and supported by the Núcleo de Telessaúde (NTES) (Telehealth Nucleus) at IMIP. Online communication tools were used, offering activities such as classes, seminars, tutoring and clinical meetings.

The opening of the 2020 school year, traditionally held in previous years at the Espaço Ciência e Cultura do IMIP (Science and Culture Space of IMIP), on March 30th, had a conference given online by the director of PAHO, with the theme: "Current challenges on health in the Americas".

In the undergraduate education, changes had taken place based on constant dialogues among the areas of teaching, research, health care and the coordination of undergraduate courses of the Instituições de Ensino Superior (IES) (Higher Education Institutions) that maintain IMIP as a teaching hospital. Part of the practical activities were suspended, students' in their final year were being kept, in small groups, mainly concentrated in outpatient clinics and wards, involving the areas of healthcare for children, women, adults and the elderly. Following some modifications due to changes in the flow of professionals and patients and areas of care in the hospital complex, guidance was given to the students, in order to ensure compliance with the necessity of health and safety measures, such as the use of PPE, social distancing and hand sanitation, following the recommendations from the health control agencies. In order to ensure that the consumption of PPE in teaching activities did not worsen, even more, the deficit of these were already scarcesupplies, the control of its dispensation was under the management of the under-graduation coordination of the institute.

The post-graduation lato sensu students kept the theoretical and practical activities, including the "COVID areas", observing all the recommended safety measures. The role of the residents in facing the pandemic was of fundamental importance for patient care.

The practical teaching experiences aimed to provide the student with in-service training during the pandemic, involving them in clinical practice, to strengthen learning in patient care and collaboration 
with preceptors in the context of the COVID-19 pandemic.

As part of the stricto sensu post-graduate program, the guidelines for Master's and Doctoral students in the academic and professional programs of the institution were maintained. Qualification and thesis defense were held in the distance modality, making a total of 126 events, from April to September, besides the publication of 88 scientific articles in indexed journals, of which eight approached topics related to the pandemic.

Regarding to the researches in progress at the institution, in order to maintain the necessary distance and safety of thepatients, remote database consultationswere maintained and data collection activities were suspended in the hospital environment.

With the support of the Núcleo Central de Estudos COVID-19 (Central Nucleus of Studies on COVID-19), established on March 17th by the Ordinance Sup. General Number 05/2020,15 and aiming at raising funds, the research groups, mobilized to evaluate the impact of the pandemic at the institution, submitted 19 research projects on COVID-19 to edicts of the Coordenação de Aperfeiçoamento de Pessoal de Nivel Superior (CAPES) (Coordination for the Improvement of Higher Level Personnel), the Conselho Nacional de Desenvolvimento Científico e Tecnológico (CNPq) (National Council for Scientific and Technological Development) and the Departamento de Ciencia e Tecnologia (DECIT-MS) (Science and Technology Department) and along with the Comitê de Ética em Pesquisa do IMIP (CEP IMIP) (Research Ethics Committee of IMIP) approved 41 studies related to the pandemic up to September 25, 2020, with eight studies concluded and the others under analysis or data collection.

The face-to-face activities at the library were suspended and some services were offered remotely, such as: research on scientific information guidance; elaboration and monitoring of advanced search on the pandemic strategies, relating to issues of the researchers'interest from the institution and cooperation with the Repositório de Estratégias de Busca (Repository of Search Strategies), powered by the Rede de Referencistas (RefNet) (Referencers Network), coordinated by Bireme; remote guidance for normalization on scientific work, protocols on assistance; and institutional strategic plans to resume activities, and among others.

\section{Strategic Management and Crisis Office}

Prior to the statement from the Public Health Emergency of International Concern issued by WHO on January 30, 2020, IMIP management had been following the progress of the disease caused by the new coronavirus and the measures and recommendations that national and international health authorities were issuing.

On January 31 st, a series of meetings was initiated with a group formed by the hospital infection control commission (HFCC), chief of the general superintendency, medical and nursing board members, hospital epidemiological surveillance (HES), medical accounts, among other managers, to plan actions focused on confronting the new coronavirus.

On March 11th - right after WHO's announcement classifying COVID-19 as a pandemic - the Committee for Prevention, Monitoring and Operational Evaluation of COVID-19 was formalized with the recommendation that all guidelines recommended by health authorities should be applied to institutional protocols (Ordinance Sup. General Number 04/2020). 16

The growing number of hospital beds and occupancy influenced the hospital management, with reflexes in the management, organization and operational of hospital beds, in the control of supplies, which are increasingly scarce and difficult to have access, and in the administration of human resources, with employees in risk groups and/or those infected by SARS-CoV-2, besides the financial area of the hospital, directly impacted by this crisis.

The pandemic has challenged strategic management skills in all areas of management. It required solutions that articulated several areas, such as assistance, financial, teaching, and transversal areas, such as purchasing and logistics of PPE distribution, and hospital supplies.

On March 26th a Crisis Office was created, by the General Superintendence, through the Ordinance Sup. General Superintendency Number 06/202017 with the aim of promoting the articulation and systematic and permanent monitoring of operational activities and logistics sectors, promoting integration and efficient response to the pandemic, composed of members of the superintendency and multi-professional support members. Daily meetings were held, essential to strengthen management, and to map sources of scientific evidence capable of supporting management practices with a greater chance of success. The tools used for the data management related to the pandemic allowed the visualization of 
indicators and the production of scenarios that helped in the decision making based on qualified information.

In order to contribute to the fight against the pandemic in different social classes and to support public health initiatives, a group of specialists from different health sectors, with subsidies from financial institutions, implemented the Todos pela Saúde 18 (Health forAll) project. The project has supported by institutions, through several collaborators, States, municipalities and health services. At IMIP, Todos pela Saúde collaborated in the consolidation of the Crisis Office, helped set up the Situation Room, included COVID-19 monitoring panel with assistance and financial indicators at the hospital complex, promoted teleconferences to discuss tools adopted in management, and provided donations for medication, supplies and equipment.

The people from the management area demanded more dedication and energy in this crisis, and one of the challenges involved the emotional sphere with the feelings of anxiety, fear, uncertainties and frustrations. Between the months of April and May, in Pernambuco, there were high peaks of the pandemic, many assistance professionals were removed and management was fundamental to keep the services working with quality, supporting and seeking initiatives such as promoting mental health for those involved in patient care; removing the professionals from the front line classified as risk groups for SARS-CoV-2, assigning them to administrative activities, telework or working in the modality at a distance (telework). The expansion of human resources was necessary to meet the demand of opening new hospital beds and replacing professionals affected by COVID-19.

At the beginning of the pandemic, there was a marked alteration in the behavior of PPE consumption in the care units and the great challenge was to manage the budget of their purchase which suffered major price readjustments or discontinuity of acquisitions due to the production and logistical problems. It was necessary to adopt the contingency of the existing stock, through controlled distribution, monitoring and training on the efficient use of this equipment.

The difficulties of acquisition and the unavailability of PPE and medicines were not enough to meet the demand at the hospital. Therefore, it was necessary to seek financial and material resources. New resources were incorporated from the federal and state governments of Pernambuco and the city of Recife, in addition to specific parliamentary amendments. The support from the civil society was present as a humanitarian and ethical gesture and commitment to life, and the institution received donations of PPE, supplies and medicines. In addition to the spirit of solidarity, it was possible to observe the creativity in making PPE, such as facial shields, masks and cloaks.

The low supply and unavailability of medicines on the market - both to treat patients affected by COVID-19 and to meet the demands of anesthesia, oncologic, cardiac and vascular surgeries and other procedures - brought another challenge to the management of the institution that implanted: daily control of stock of critical items, list of replacements, negotiation of acquisition directly with manufacturers and monitoring the forecast delivery of these products to distributors, in order to minimize the shortage.

The communication strategy adopted by IMIP through the Daily Newsletter allowed members of the Crisis Bureau and health specialists to transmit to the professionals of the institution, scientific evidence and situational indicators, in order to provide greater use of the strategies to confront the pandemic, in addition to avoid divergent practices or guided by publications not yet validated by its peers. The newsletter also played an important role in bringing scientific and situational information about the pandemic to society, offering content validated by specialized and qualified professionals, avoiding the spread of false information about conducts and recommendations on prevention and measures related to COVID-19.

The constant follow-up of management at the institution with various sectors at the hospital, aligned the protocols and recommendations of the health authorities, was fundamental for the assertive decision making, synchronized with each phase of the pandemic in our region (Figure 3 ). With the support of professionals from all the areas of the institution, IMIP management was able to record and organize the situational data of the pandemic to analyze and plan actions to gradually return to its activities.

\section{Resuming}

With daily monitoring of the situation of the pandemic in the world, and especially in the state of Pernambuco and the capital, Recife, it was possible to observe the decline of cases, monitoring the measures adopted by the local health authorities and from that, begin to plan a gradual resumption of hospital activities in the spheres of care, teaching and research. 


\section{CHRONOLOGY OF MEASURES}

\section{MARCH 2020}

$01 / 31$ to $03 / 12$

Qualified teams and

Protocols of the Institution

Reference for care for pregnant women, puerperal and newborns suspected of COVID-19
Prevention Committee Instit

nstitution, Monitorin

Evaluation of COVID-19.

Ordinance Sup. General number 04/2020

Central Nucleus of Studies on COVID-19.

Ordinance Sup. General number 05/2020

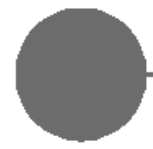

$\dot{8}$

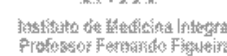

$03 / 21$

Institution of the Crisis Bureauon COVID-19

Ordinance Sup. General number 06/2020
$03 / 17$

pening of 8 hospital beds in the Nursing Obstretric IMIP SENDS OUT AN OFFICIAL COMMUNICATION ON COVID-19

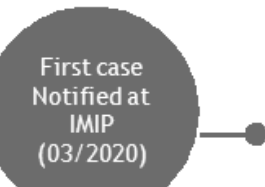

$03 / 2$

Opening of $10 \mathrm{ICU}$ hospital beds

Opening of 02 hospital beds for Pediatric ICU 
Chronology of measures adopted at IMIP during COVID-19 pandemic.

CHRONOLOGY OF MEASURES

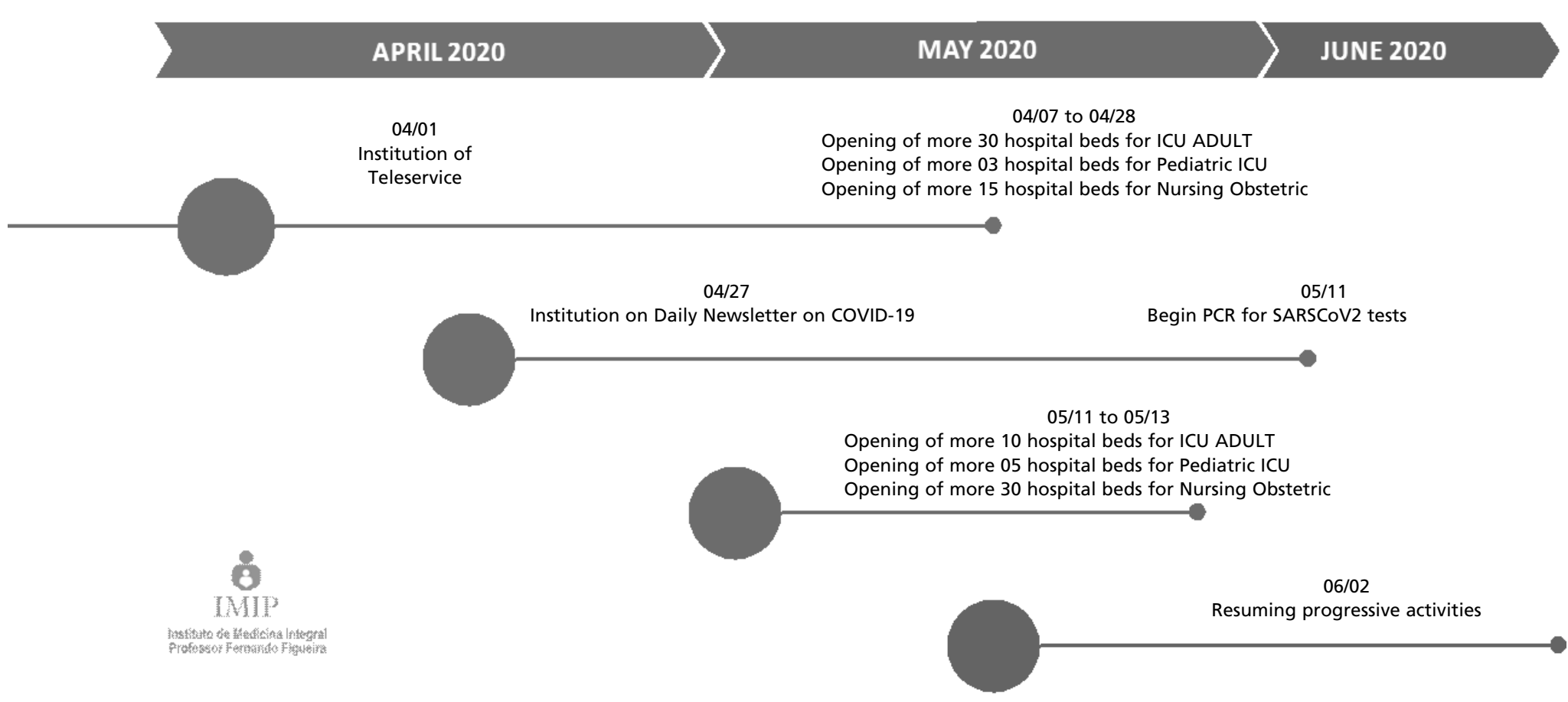


To this end, the General Superintendency - with the support of the Crisis Office - began plans for resumption with more detailed sharing of information on the pandemic for directors and coordinators of all areas of the institution, through online meetings interactingwith participants aiming to build together the return of the activities with limitations and care recommended by the health authorities.

Plans for the resumption in the care services, teaching and research activities and sectors were prepared, all in a gradual and systematic manner, with the appropriate follow-up by their respective superintendencies. From the healthcare services, preestablished schedules were elaborated, and the resumption started with the reoccupation of outpatient agendas, with the increase of elective surgeries, followed by several types of transplants, conse-

\section{References}

1. Rothan HA, Byrareddy SN. The epidemiology and pathogenesis of coronavirus disease (COVID-19) outbreak. J Autoimmun. 2020; 109 (2020): 102433.

2. Brasil. Ministério da Saúde. Secretaria de Vigilância à Saúde. Centro de Operações de Emergências em Saúde Pública. Bol Epidemiol 01. Brasília, DF; 3 fev 2020.

3. ANVISA (Agência Nacional de Vigilância Sanitária). Nota Técnica GVIMS/GGTES/ANVISA N ${ }^{\circ}$ 03/2020. Sistema Nacional de Vigilância Epidemiológica das Infecções Relacionadas à Assistência à Saúde (IRAS) e Resistência Microbiana (RM) em Serviços de Diálise. Brasília, DF; 20 jan 2020.

4. ANVISA (Agência Nacional de Vigilância Sanitária). Nota Técnica GVIMS/GGTES/ANVISA N $\mathrm{N}^{\circ} \quad 04 / 2020$ Orientações para serviços de saúde: medidas de prevenção e controle que devem ser adotadas durante a assistência aos casos suspeitos ou confirmados de infecção pelo novo coronavírus (SARS-CoV-2). Brasília, DF; 31 mar 2020.

5. Pernambuco. Secretaria Estadual de Saúde. Boletim COVID-19 N N $^{\circ}$ 188. Recife, 04 set 2020

6. WHO (World Health Organization). Transmission of SARS-CoV-2: implications for infection prevention precautions [Internet]. Geneva; 2020 jul 09 [cited 2020 sep 27]. Available from: https://www.who.int/news-room/commentaries/detail/transmission-of-sars-cov-2-implications-forinfection-prevention-precautions

7. Pernambuco. Secretaria Estadual de Saúde. Protocolo Clínico Epidemiológico do Novo Coronavírus (COVID19), versão $\mathrm{N}^{\circ} 01$. Recife; fev 2020.

8. Pernambuco. Secretaria Estadual de Saúde. Nota Técnica SEVS No $187 / 2020$. Recife; 2020.

9. IMIP (Instituto de Medicina Integral Prof. Fernando Figueira). Protocolo de atendimento aos casos suspeitos ou confirmados de infecção pelo novo coronavírus na neonatologia IMIP. Recife; 2020 quently increasing - the hospital occupation rate. As for teaching and research, the return to practical activities gradually began with activities in the field of care, and in support sectors such as the library and secretary, face-to-face care was resumed with the appropriate protective measures for professionals and patientsat the services. All processes were based on a set of strategies of care, security, protection and prevention to avoid the transmission of SARS-CoV2 and to meet different demands of the institution.

\section{Authors' contribution}

All contributed equally in all stages of the article.

10. IMIP (Instituto de Medicina Integral Prof. Fernando Figueira). Protocolo assistencial para atendimento de gestantes e puérperas com infecção suspeita ou confirmada por COVID-19 no CAM-IMIP. Recife; 2020. Disponível em: http://www1.imip.org.br/imip/arquivos/noticia/ PROTOCOLO-COVID19_CAM_15abr2020_13h.pdf

11. IMIP (Instituto de Medicina Integral Prof. Fernando Figueira). Orientações para o atendimento a pacientes adultos, pediátricos, gestantes e puerpéras de casos suspeitos e confirmados de infecção pelo novo coronavírus (COVID-19). Recife; 2020. Disponível em: http://imipintranet/imip/noticias/documentos/PROTOCOLO-DEATENDIMENTO-COVID19-23-03-2020.pdf

12. ANVISA (Agência Nacional de Vigilância Sanitária). Nota Técnica GVIMS/GGTES/ANVISA N $\mathrm{N}^{\circ} \quad 07 / 2020$ Orientações para prevenção e vigilância epidemiológica das infecções por SARS-CoV-2 (COVID-19) dentro dos serviços de saúde: (complementar à nota técnica GVIMS/GGTES/ANVISA Nº 04/2020). Brasília, DF; 05 ago 2020.

13. ANVISA (Agência Nacional de Vigilância Sanitária). Resolução RDC N ${ }^{\circ}$ 50, de 21 de fevereiro de 2002. Dispõe sobre o regulamento técnico para planejamento, programação, elaboração e avaliação de projetos físicos de estabelecimentos assistenciais de saúde. Brasília, DF; 2003.

14. Brasil. Ministério da Saúde. Portaria No 467, de 20 de março de 2020. Dispõe, em caráter excepcional e temporário, sobre as ações de Telemedicina, com o objetivo de regulamentar e operacionalizar as medidas de enfrentamento da emergência de saúde pública de importância internacional previstas no art. $3^{\circ}$ da Lei $n^{\circ} 13.979$, de 6 de fevereiro de 2020, decorrente da epidemia de COVID-19. Diário Oficial da União [DOU]. Brasília, 23 mar 2020; Seção 1 - Extra, p. 1.

15. IMIP (Instituto de Medicina Integral Prof. Fernando Figueira). Portaria Sup. Geral No 05/2020. Recife; 17 mar 
2020. Disponível em: http://10.0.0.100/imip/normativos/ arqs/PORTARIA_SG_05_2020.pdf

16. IMIP (Instituto de Medicina Integral Prof. Fernando Figueira). Portaria Sup. Geral No 04/2020. Recife; 13 mar 2020. Disponível em: http://10.0.0.100/imip/downloads/ documentos/Portaria-Sup-Geral-n-04.2020.pdf

17. IMIP (Instituto de Medicina Integral Prof. Fernando Figueira). Portaria Sup. Geral No 06/2020. Recife; 26 mar 2020. Disponível em: http://server.informazione.com.br/ imip/arquivos/noticia/Untitled_20200326_172231.PDF
18. Fundação Itaú para Educação e Cultura [Internet]. Todos pela saúde: uma aliança contra a Covid-19 [Internet]. São Paulo; 2020 [acesso em 25 set 2020]. Disponível em: https://www.todospelasaude.org/

Received on September 23, 2020

Approved on October 30, 2020 